\title{
IMPACT OF DEBT TO ASSET RATIO (DAR), DEBT TO EQUITY RATIO (DER), CAPITAL STRUCTURE (STM) TO RETURN ON EQUITY ( ROE) IN TEXTILE MILL PRODUCTS INDUSTRIAL COMPANY ARE REGISTERED ON THE BEI
}

\author{
Edwin Bustami ${ }^{1)}$, Syamsurijal Tan ${ }^{2)}$, Zulkifli $^{3)}$ \\ ${ }^{1)}$ STIA Nusantara Sakti, Sungai Penuh, Indonesia \\ 2,3) Faculty of Economics and Business, Universitas Jambi, Indonesia \\ Corresponding author:edwinbustami@gmail.com
}

\begin{abstract}
This study aims to analyze the development / change of DAR, DER, STM, and ROE, Effect of DAR, DER, and STM on ROE both simultaneously and partially, the magnitude of the effect of DAR, DER, and STM on ROE both simultaneously and partially, as well as variables the most dominant one affects ROE. DAR, DER, STM simultaneously have a significant effect on ROE. While partially for the DAR variable no effect on ROE. for the DER variable it affects ROE. for STM variables it is known that the effect has an effect on ROE. The magnitude of the effect simultaneously from DAR, DER, STM to ROE is 0.94 or $94 \%$. The magnitude of the effect of DAR on ROE is equal to 22.8\%. The magnitude of the effect of DER on ROE is $74.9 \%$. The magnitude of the effect of STM on ROE is 50\%. DER variable is the variable that has the most dominant effect on ROE with a value of $74.9 \%$.
\end{abstract}

Key word : Debt to Asset Ratio (DAR), Debt to Equity Ratio (DER), Capital Structure (STM), Return on Equity (ROE)

\section{Introduction}

According to Sutrisno (2009), financial ratios that can be used to assess a company's financial performance include liquidity ratios or leverage ratio, leverage ratio, activity ratio or activity ratio, profit ratio or Prifitability Ratios, valuation ratio or Valuation Ratios.

In financial management the use of financial ratios presented by companies is usually to answer important questions about the company's operational performance, one of which is how the company funds its assets. The ratio used is the leverage ratio. According to Yogo Purnomo (1998) this ratio explains the proportion of the sources of short-term or long-term funding for the use of company assets. In addition, another thing that can be revealed from the leverage ratio is the tendency of the business capital structure, whether the company uses debt financing more or concentrates more on its own capital (equity) in the business capital structure. meaning that the leverage ratio is reflected in the amount of Debt to Equity Ratio (DER) and Debt to Total Asset Ratio (DAR).

Tandellin (2010) states that leverage ratios are important for investors in assessing company performance, because the goal of investors in investing is to maximize returns without forgetting the investment risk factors they face. Return is one of the factors that motivate investors to invest and is also a reward for the courage of investors to bear the risk of investments made.

The risk referred to by Indriyo Gitosudarmo (1994) is called financial risk, where if the issuer is unable to fulfill its financial obligations, investors who own shares of the company risk not receiving dividends or even losing capital if the company is liquidated.

While according to Weston Copeland (1992) companies with low leverage ratios have a lower risk of loss if economic conditions decline, but also have lower returns if economic conditions improve. Conversely, companies with high leverage ratios carry a large risk of loss, but also have the opportunity to earn high profits. The prospect of high returns is desirable, but investors are generally afraid of risks so the decision to use leverage must balance the high returns to increased risk.

Textile Mill Products Industrial Company is a company engaged in the textile industry, where the raw materials needed are generally imported from outside. Companies in carrying out their operational activities require large funding sources from within the company and from outside the company. So that the results of the Textile Mill Products industry have an important contribution to the construction of physical facilities in Indonesia, besides that there are also industrial products exported abroad.

The average development of assets owned by the Textile Mill Products Industry company listed on the Indonesia Stock Exchange (IDX) for the 2008-2010 period has fuluctuated annually. In 2008 the average 
assets were Rp. 623,349,734.11. In 2009 it decreased to Rp 556,448,885.11 or decreased by $-0.11 \%$, and in 2010 it again declined to $\mathrm{Rp} 558,068,457.67$ or decreased by $0.0029 \%$. When viewed as a whole, it is obtained an illustration that during the period 2008-2010 the average assets experienced a tendency to fluctuate every year.

While the development of the company's own capital as a source of expenditure can be seen in the table below, it can be seen that the average own capital owned by the Textile Mill Products Industry company listed on the Indonesia Stock Exchange (IDX) for the 2008-2010 period has increased every year. In 2008, the average capital was Rp. 110,931,101.33. In 2009 it rose to Rp 120,397,669.56 or increased by $0.09 \%$, and in 2010 it rose again to Rp $155,070,540.33$ or increased by $0.29 \%$. When viewed as a whole, it is obtained an illustration that during the period 2008-2010 the average capital itself experienced an increasing trend each year.

Meanwhile, the development of debt owned by companies incorporated in the Textile Mill Products Industry listed on the Indonesia Stock Exchange (BEI) for the period 2008-2010 shows that the average debt held by Textile Mill Products Industry companies is listed on the Indonesia Stock Exchange (BEI) period 2008-2010 has decreased every year. In 2008, the average debt was IDR 510,202,077.11. In 2009 it declined to $\mathrm{Rp} 436,017,091.44$ or decreased by $-0.15 \%$, and in 2010 it declined to Rp 402,974,980.67 or decreased by $-0.08 \%$. When viewed as a whole, it is obtained an illustration that during the period 2008-2010 the average debt experienced a downward trend every year.

Meanwhile the development shows that the average long-term debt owned by the Textile Mill Products Industry listed on the Indonesia Stock Exchange (IDX) for the period 2008-2010 has a tendency to fluctuate every year. In 2008, the average total debt was Rp. 210,426,748.22. In 2009 it declined to Rp. $186,261,533.11$ or decreased by $-0.11 \%$, and in 2010 it rose again to Rp. $224,979,472.00$ or increased by $0.21 \%$. When viewed as a whole, it can be seen that during the period 2008-2010 the average long-term debt experienced a tendency to fluctuate every year.

The development of EAT owned by companies incorporated in the Textile Mill Products Industry listed on the Indonesia Stock Exchange (IDX) for the 2008-2010 period is as follows: it is seen that the average EAT of the Textile Mill Products Industry company is listed on the Indonesia Stock Exchange (IDX) for the period 2008-2010 experienced a tendency to fluctuate every year. In 2008 the average EAT was Rp. $77,880,352.44$. In 2009 it decreased to Rp. 385,680.89 or decreased by $-1.00 \%$, and in 2010 it rose again to Rp. $12,002,660.89$ or an increase of $30.12 \%$. When viewed as a whole, it can be seen that during the 20082010 period the long EAT average experienced fluctuating trends every year.

According to Bambang Riyanto (1981) that the amount of foreign capital under any circumstances should not exceed the amount of its own capital. Debt ratio is a comparison between the amount of foreign capital and its own capital does not exceed 1: 1 or in other words Debt Ratio or Leverage Do not be greater than $50 \%$, so that guaranteed foreign capital is not greater than the capital that is guaranteed. The amount of debt used as a source of capital needs to be controlled so that the company is always in a healthy condition.

This is in accordance with the opinion of Lukman Syamsudin (1992), the use of debt as a source of expenditure needs to be considered, because the use of debt that is too high can also cause high risk, namely in the form of a fixed burden that must be borne by the company. Because interest payments to creditors on capital borrowed by the company must take precedence before profits can be shared with shareholders. Shareholders and prospective shareholders (investors) are very concerned about the amount of debt and the ability of companies to pay interest and principal loans.

The creditors also pay attention to the amount of the company's loans, because the bigger the loan the greater the possibility of the company not being able to pay interest and principal loans. If the company is unable to overcome high debt problems, it shows the inability of the company to improve its performance, which results in a decrease in stock prices, so the company is feared unable to share the expected benefits of investors in the form of capital gains and dividends.

Generally investors expect profits from high stock prices and refuse to accept high risks. Companies need to have a strategy in making the right funding decisions, so that the company's goals to maximize company value and prosperity of shareholders can be achieved, which is reflected in the increase in the company's stock price.

\section{Literature Review}

Some understanding will be explained below so that there is no misunderstanding in translating a term, as well as to get a unity of meaning and provide an understanding of the terms used in this study.

\section{Debt to Asset Ratio (DAR)}

Kasmir (2010), Debt to Asset Ratio (DAR) is the debt ratio to measure the ratio between total debt and total assets. In other words, how much the company's assets are financed by debt or how much the company's debt affects the management of assets. 
From the measurement results, if the ratio is high, meaning that funding with more debt, it is increasingly difficult for companies to obtain additional loans because it is feared that the company is unable to cover its debts with its assets. Likewise, if the ratio is low, the smaller the company is financed by debt. Measurement standards for assessing whether or not the ratio of the company is used are the same industry average ratio.

To determine of number of Debt to Asset Ratio (DAR) in this reseach using formula as following:

$$
\text { DAR }=\frac{\text { Total of Debt }}{\text { Total of Asset }}
$$

\section{Debt to Equity Ratio (DER)}

Kasmir (2010), Debt to Equity Ratio (DER) is the ratio used to assess debt with equity. This ratio is sought by comparing all debts, including smooth debt with all equity. This ratio is useful for knowing the amount of funds provided by the borrower (creditor) with the owner of the company. In other words, this ratio serves to know every rupiah of its own capital which is used as collateral for debt.

For creditors, the greater the ratio, the more unprofitable because the greater the risk borne for failures that may occur in the company. However, for the company, the greater the ratio, the better. Conversely with a low ratio, the higher the level of funding provided by the owner and the greater the security limit for the borrower in the event of loss or depreciation of the value of assets. This ratio also provides general instructions on the feasibility and financial risks of the company.

$$
\mathrm{DER}=
$$

$$
\text { Long Term Debt }
$$

$$
\text { Equity }
$$

\section{Capital Structure}

Capital structure is a mixture of long-term funding sources used by the company. The purpose of management of capital capital structure is basically to integrate the parmanen funding sources used by the company in a way that can maximize the value of the company.

According to Suad Husnan (1999), capital structure is a comparison between long-term funding sources that are loan-based and own capital. If the definition of all debt is included (both long-term debt and shortterm debt), the comparison is called the financial structure or financial structure. However, keep in mind that sometimes a formal debt is short-term (one year or less one year), but because it is always extended, it is basically a long-term debt.

$$
\mathrm{STM}=\frac{\text { Long Term Debt }}{\text { Equity }}
$$

\section{Return on Equity (ROE)}

According to Kasmir (2010) the returns on equity or Return on Equity (ROE) or own capital profitability is a ratio to measure net income after tax with own capital. This ratio shows the efficiency of the use of own capital. The higher this ratio, the better. This means that the position of the company owner is getting stronger, and vice versa.

Return on Equity $(\mathrm{ROE})=$

Earning after Interest andf Tax

\section{FRAMEWORK}

$$
\text { Equity }
$$

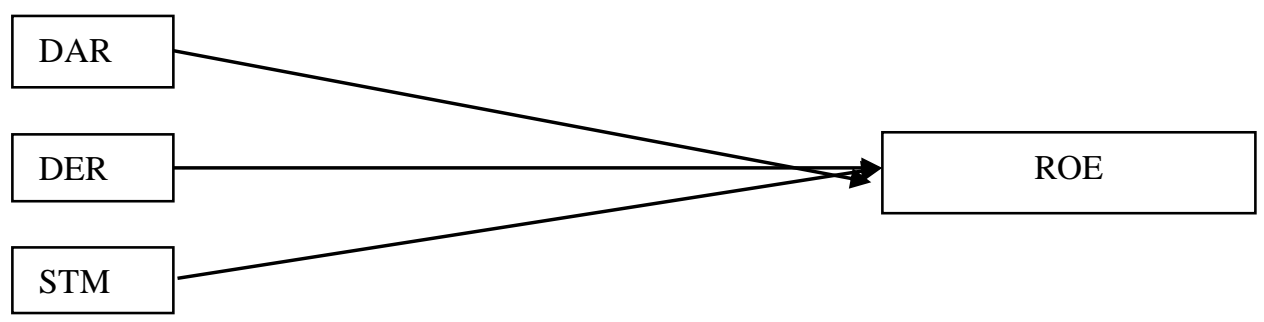




\section{Research Hypothesis}

Based on the results of previous studies, the hypothesis can be determined as follows:

H1 There is a significant effect simultaneously from Debt to Asset Ratio (DAR), Debt to Equity Ratio (DER), and Capital Structure (STM) to Return on Equity (ROE)

H2 There is a partially significant effect of Debt to Asset Ratio (DAR), Debt to Equity Ratio (DER), and Capital Structure (STM) on Return on Equity (ROE)

H3 There is a dominant influence on Debt o Asset Ratio (DAR) on Return on Equity (ROE)

\section{RESEARCH METHODS}

\section{Population and Samples \\ Population}

The population in this study are all companies included in the Textile Mill Products industry which are listed on the Indonesia Stock Exchange for the period 2008-2010 which consists of 9 companies, namely; PT. Argo Pantes Tbk, PT. Century Textile Industry Tbk, PT. Eratex Djaja Tbk, PT. Panasia Filament Inti Tbk, PT. Panasia Indosyntec Tbk, PT. Roda Vivatec Tbk, PT. Sunson Textile Manufacturer Tbk, PT. Tifico Fiber Indonesia Tbk, and PT. Unitex Tbk.

\section{Sample}

Sampling method using Purposive Sampling method, meaning that the population that will be used as a sample in the study is a population that meets certain sample criteria in accordance with what the researcher wants. In this study researchers draw samples from companies that meet the criteria, namely the availability of variable data examined by researchers such as 7 Shareholder Equity companies that have the best rating from 9 companies and Earning After Tax (EAT) 7 companies that have the best rating from 9 companies during the study period.

As for the 7 companies that were used as samples in this study are as follows: PT. Century Textile Industry Tbk, PT. Eratex Djaja Tbk, PT. Panasia Indosyntec Tbk, PT. Roda Vivatec Tbk, PT. Sunson Textile Manufacturer Tbk, PT. Tifico Fiber Indonesia Tbk, and PT. Unitex Tbk.

Operational variables

\begin{tabular}{|c|c|c|c|c|c|}
\hline No & Variable concept & Indikator & & Formula & Unit \\
\hline 1 & $\begin{array}{l}\text { debt to Total Assets Ratio (DAR) } \\
\text { is an illustration of the proportion } \\
\text { of all debts used to finance all } \\
\text { assets in the industry }(X 2)\end{array}$ & $\begin{array}{ll}- & \text { Total debt } \\
- & \text { Total assets }\end{array}$ & $\mathrm{DAR}=$ & $\frac{\text { Tot.Debt }}{\text { Tot.Assets }} \times 100$ & $\%$ \\
\hline 2 & $\begin{array}{l}\text { Debt to Equity Ratio (DER) is a } \\
\text { picture of the proportion of total } \\
\text { debt used for all equity or } \\
\text { Shareholder Equity }(X 1)\end{array}$ & $\begin{array}{ll}- & \text { Total Debt } \\
- & \text { Shareholder } \\
& \text { Equity }\end{array}$ & DER = & $\frac{\text { Tot.Debt }}{\mathrm{SE}} \times 100$ & $\%$ \\
\hline 3 & $\begin{array}{l}\text { Capital Structure (STM) describes } \\
\text { the company's activities funded by } \\
\text { long-term debt }\end{array}$ & $\begin{array}{ll}\text { - } & \text { Long-term debt } \\
\text { - } & \text { Shareholder } \\
& \text { Equity }\end{array}$ & $\mathrm{STM}=$ & $\frac{\text { LTD }}{\mathrm{SE}} \times 100$ & $\%$ \\
\hline 4 & $\begin{array}{l}\text { Return on Equity (ROE), describes } \\
\text { the ability of companies to obtain } \\
\text { net income by using their own } \\
\text { capital }\end{array}$ & $\begin{array}{ll}- & \text { EAT } \\
- & \text { Shareholder } \\
& \text { Equity }\end{array}$ & $\mathrm{ROE}=$ & $\frac{\text { EAT }}{\text { MS }} \times 100$ & $\%$ \\
\hline
\end{tabular}

\section{Results and Discussion}

Analysis of the Effect of DAR, DER, and STM on ROE

\section{F Test Statistics}

Ho: DAR, DER, STM together have no effect on ROE Ha: DAR, DER, STM jointly influence ROE 
ANOVA $^{b}$

\begin{tabular}{rlrrrrr}
\hline & Model & Sum of Squares & Df & Mean Square & F & Sig. \\
\hline 1 & Regression & 16.924 & 3 & 5.641 & 89.164 & $.000^{\mathrm{a}}$ \\
& Residual & 1.076 & 17 & .063 & & \\
& Total & 18.000 & 20 & & & \\
& & & & & & \\
\end{tabular}

a. Predictors: (Constant), STM, DAR, DER

b. Dependent Variable: ROE

Based on table 5.6 above Fcount $>$ F table $(89.164>3.197)$ and significance $<0.05 .(0,000<0,05)$, then Ho is rejected. So it can be concluded that DAR, DER, and STM jointly influence ROE.

\section{2. $\mathbf{t}$-test Statistics}

- Testing the variable coefficients of DAR

Ho: DAR has no effect on ROE

Ha: DAR has an effect on ROE

Coefficients (a)

\begin{tabular}{|c|c|c|c|c|c|c|}
\hline & \multirow[t]{2}{*}{ Model } & \multicolumn{2}{|c|}{ Unstandardized Coefficients } & \multicolumn{3}{|l|}{$\begin{array}{l}\text { Standardized } \\
\text { Coefficients }\end{array}$} \\
\hline & & $\mathrm{B}$ & Std. Error & Beta & $\mathrm{t}$ & Sig. \\
\hline \multirow[t]{4}{*}{1} & (Constant) & $-1.369 \mathrm{E}-8$ & .055 & & .000 & 1.000 \\
\hline & DAR & -.061 & .064 & -.061 & -.967 & .347 \\
\hline & DER & -.672 & .144 & -.672 & -4.667 & .000 \\
\hline & STM & -.338 & .142 & -.338 & -2.381 & .029 \\
\hline
\end{tabular}

a. Dependent Variable: ROE

Based on table 5.7 above, it is known that the value of $-\mathrm{t}$ table $\leq \mathrm{t}$ count $\leq \mathrm{t}$ table $(-2,110 \leq-0,96712,110)$ and significance $>0.05(0.347>0.05)$, then Ho is accepted. So it can be concluded that partially DAR has no effect on ROE

- Testing the coefficient of the DER variable

Ho: DER has no effect on ROE

Ha: DER has an effect on ROE

Based on table 5.7 above, it is known that the calculated t-value <-t table $(-4.667<2.110)$ and significance $>0.05(0.00>0.05)$, then Ho is rejected. So it can be concluded that DER has an effect on ROE

- Testing STM variable coefficients

Ho: STM does not affect ROE

Ha: STM has an effect on ROE

Based on table 5.7 above, it is known that the calculated t-value <-t table $(-2.381<2.110)$ and significance> $0.05(0.029>0.05)$, then Ho is rejected. So it can be concluded that STM has an effect on ROE 
Analysis of the magnitude of the effect of DAR, DER, and STM on ROE

1. Large analysis of simultaneous or together influences

Model Summary (b)

\begin{tabular}{cccc} 
Model & R & R Square & Adjusted R Square \\
\hline 1 & $.970^{\mathrm{a}}$ & .940 & .930 \\
\hline
\end{tabular}

a. Predictors: (Constant), STM, DAR, DER

b. Dependent Variable: ROE

Based on the multiple detremination coefficient table for the DAR, DER, and STM variables above, by looking at the Adjusted R Square value, it can be seen the effect of Debt to Asset Ratio (DAR), Debt to Equity Ratio (DER) and Capital Structure (STM) on Return on Equity (ROE) which is equal to 0.930 or 93\%. This shows that simultaneously variations of DAR, DER, and STM can explain variations (movement patterns) of ROE values of $93 \%$ and the remaining $7 \%$ still have other variables that are not explained or in other words that variations can be explained by other variables by $7 \%$.

\section{Large analysis of partial or individual influences}

\begin{tabular}{lllllll}
\multicolumn{1}{c}{} & \multicolumn{3}{c}{ Coefficients (a) } \\
Model & & $\begin{array}{l}\text { Correlations } \\
\text { Zero-order }\end{array}$ & Partial & Part & \multicolumn{2}{c}{ Collinearity Statistics } \\
\hline 1 & (Constant) & & & & & VIF \\
& DAR & .291 & -.228 & -.057 & .870 & 1.150 \\
& DER & -.958 & -.749 & -.277 & .169 & 5.904 \\
& STM & -.929 & -.500 & -.141 & .174 & 5.744 \\
\hline
\end{tabular}

a Dependent Variabel : ROE

Based on the partial detremination coefficient table for the DAR, DER, and STM variables above, by looking at Partial values it can be seen that the effect of Debt to Asset Ratio (DAR) on Return on Equity (ROE) is 0.228 or $22.8 \%$. This shows that partially the DAR variation can explain variations (movement patterns) of the ROE value of 22.8\%. The magnitude of the effect of Debt to Asset Ratio (DER) on Return on Equity (ROE) is 0.749 or $74.9 \%$. This shows that partially the variation of DER can explain variations (movement patterns) of the ROE value of 74.9\%. The magnitude of the effect of Capital Structure (STM) on Return on Equity (ROE) is equal to 0.500 or $50 \%$. This shows that partially the STM variation can explain variations (movement patterns) of the ROE value of $50 \%$.

\section{Variable analysis that has dominant influence on ROE.}

Based on the value of the partial determination coefficient table above, it is known that the partial value for DAR is 0.228 or $22.8 \%$, the partial value for DER is 0.749 or $74.9 \%$, and the partial value for STM is 0.500 or $50 \%$. Based on the values of the Partial Determination coefficient table in the table above it can be determined that the variable Debt to Equity Ratio (DER) of $74.9 \%$ is the most dominant variable affecting Return on Equity (ROE). When compared with the results of previous studies according to Mursidi (2006) Variable Return on Investment (ROI) is the dominant variable compared to the variable Debt Ratio (DR) in giving effect to changes that occur in the variable Return on Equity (ROE).

\section{CONCLUSIONS AND RECOMMENDATIONS}

\section{Conclusions}

1. Debt to Asset Ratio DAR changes fluctuate with an average DAR change of $0.92 \%$. DER Debt to Equity Ratio experienced a fluctuating change with an average DER change of $74.03 \%$. Meanwhile the STM Capital Structure has increased with the average STM change of $27.89 \%$. And the development of ROE has fluctuated changes with an average change in ROE of $-4.96 \%$.

2. Debt to Asset Ratio (DAR), Debt to Equity Ratio (DER), Capital Structure (STM) simultaneously or together have a significant effect on ROE. This can be proven through the F test statistic test using SPSS where the value of Fcount $>$ Ftable $(89,164>3,197)$ and significance $<0,05(0,000<0,05$. While partially referring to the statistical test $\mathrm{t}$ for the DAR variable it is known that the value $-\mathrm{t}$ table $\leq \mathrm{t}$ count $\leq \mathrm{t}$ table 
$(-2,110 \leq-0,96712,110)$ and significance $>0,05(0,347>0,05)$, then Ho is accepted, so it can be concluded that partially DAR has no effect on ROE. DER is known as the value of t-count <-t table ($4.667<2.110)$ and significance $>0.05(0.00>0.05)$, then Ho is rejected, so it can be concluded that DER has an effect on ROE for known STM variables that -t count <-t table $(-2,381<2,110)$ and significance> 0.05 (0.029> 0.05), then Ho is rejected, so it can be concluded that STM has an effect on ROE.

3. The magnitude of the effect simultaneously from Debt to Asset Ratio (DAR), Debt to Equity Ratio (DER), Capital Structure (STM) to Return on Equity (ROE) is 0.94 or 94\%. Judging from the partial determination coefficient ( $\mathrm{r} 2$ ) it is known that the effect of Debt to Asset Ratio (DAR) on Return on Equity (ROE) is equal to 0.228 or $22.8 \%$. The magnitude of the effect of Debt to Asset Ratio (DER) on Return on Equity (ROE) is 0.749 or $74.9 \%$. The magnitude of the effect of Capital Structure (STM) on Return on Equity (ROE) is equal to 0.500 or $50 \%$.

4. Based on the magnitude of the partial determination coefficient value (r2) above, it can be seen that the variable Debt to Equity Ratio (DER) is the variable that has the most dominant effect on Return on equity (ROE) with a value of 0.749 or $74.9 \%$.

\section{Recommendations}

1. Companies in setting DAR, DER, STM policies that are pursued should receive special attention, the company's ability to finance debt-sourced assets must receive special attention, as well as the company in managing long-term debt and the company's own capital. companies need to seek optimal capital structure where theoretically the maximum reaches $100 \%$ or 1: 1 . But it is still calculated about the amount of capital costs that are able to equalize the additional cost of loan capital with additional profits due to the additional capital itself.

2. To take advantage of the larger capital structure of the loan source (debt), basically requires a total commitment from all members, especially managers who have to work professionally because the loan capital carries considerable risk in the cost of expenses, but still promises a return that also great if used optimally.

3. To encourage investor motivation, effective management of debt, long-term debt to own capital is carried out as well as an illustration of the capital structure used.

4. Partially from the three independent variables that influence ROE are DER and STM. So, in the future, all management components will be started. Top management, to the lowest level, should seriously consider the use of total debt and long-term debt in financing company activities, because there is an interest burden that will be issued from each debt debt to be used.

5. Based on the partial influence, then in the future the DAR variable that shows the comparison between total debt to total assets should receive special attention so that in order to give a positive contribution to the value of the company, the DER variable that has the greatest influence in the future must still get attention from management in order to always be able to make a large contribution to the value of the company, as well as the variable STM kedpan also still have to improve management

\section{References}

Agus sabardi, (1995), Manajemen Keuangan, Jilid I dan II, UPP AMP YKPN, Yogyakarta

Bambang Riyanto, Tahun 2001, Dasar-DAsar Pembelanjaan Perusahaan, Edisi Pertama, BPFE, Yogyakarta

Bustami, tahun 2007, Analisis Leverage Ratio Debt to Equity Ratio dan Debt to Total Asset Ratio dan Pengaruhnya Terhadap Harga Saham Pada Industri Automotive dan Komponennya di Bursa Efek Jakarta Periode 2002-2005, MM-UNJA, Jambi

Djarwanto PS dan Pangesti Subagyo, tahun 1994, Statistik Induktif, Edisi keempat, BPFE, Yogyakarta

Duwi Priyatno, tahun 2009, Belajar Olah Data Dengan SPSS 17, Andi Yogyakarta

Eduardus Tandelilin, Tahun 2010, Portofolio dan Investasi Teori dan Aplikasi, Edisi Pertama, Kanasius, Yogyakarta.

Farid Djahidin, 1991, Analisa Laporan Keuangan, BPFE UGM, Yogyakarta

Harnanto, 1991, Analisa Laporan Keuangan, YKPN, Yogyakarta

Indriyo Gitosudarmo, M.Com (hans), Tahun 1994,Manajemen Keuangan, Edisi Ketiga, BPFE, Yogyakarta.

Kasmir, Tahun 2010, Analisis Laporan Keuangan, Edisi I, Cetakan ke 3, PT. Rajawali, Jakarta

Kasmir, Tahun 2010, Pengantar Manajemen Keuangan, Edsis I, Cetakan I, Kencana, Jakarta

Lukman Samsudin, Tahun 1992, Manajemen Keuangan Perusahaan (Konsep dan Aplikasi Dalam Perencanaan, Pengawasan, dan Pengambilan Keputusan), Edisi Baru, Rajawali Pers, Jakarta.

Mursidi, TAhun 2006, Pengaruh Return On Investment dan Debt Ratio Terhadap Return On Equity Pada Industri Farmasi Di Bursa Efek Jakarta Periode 2001-2003, MM-UNJSA, Jambi

Napa J. Awat, Tahun 1999, Manajemen Keuangan(Pendekatan Matematis), Gramedia Pustaka Utama, Jakarta

Panji Anoraga, Piji Pakarti, tahun 2001, Pengantar Pasar Modal, PT. Rineka Cipta, Jakarta

S. Munawir, Tahun 1999, Analisa Laporan Keuangan, Edisi Keempat, Penerbit Liberti, Yogyakarta 
Sawiji Widiatmojo, TAhun 1996, Cara Sehat investasi di Pasar Modal, Edisi Ketiga, Jurnalindo Aksara Grafika, Jakarta

Sutrisno, Tahun 2009, Manajemen Keuanga Teori Konsep dan Aplikasi, Edisi Pertama, Ekonisia, Yogyakarta

Suad Husnan, Tahun 1994,Dasar-Dasar Teori Portofolio sekuritas, Edisi Kedua, UPP AMP YKPN

Suad Husanan, Tahun 1998, Manajemen Keuangan, Edisi Kedua, UPP AMP YKPN

Syafrido, 2003, Analisis Pengaruh Leverage Ratio, Asset Turn Over dan Net Profit Margin Terhadap Return On Equity Studi Kasus Pada Industri Rokok Yang Terdaftar Pada BEJ Tahun 1994-2001, MMUNJA, Jambi

Yogo purnomo, 1998,Usahawan, No. 12, Tahun XXVIII Desember 1998

Weston F. Copeland, Tahun 1992, Manajemen Keuangan, Edisi Kedelapan, Jilid Pertama, Binarupa Aksara, Jakarta 